\title{
PENGARUH SUHU DAN WAKTU PENGERINGAN TERHADAP AKTIVITAS ANTIOKSIDAN DAN SIFAT SENSORIS TEH HERBAL CELUP DAUN RAMBUSA (Passiflora foetida L.)
}

\author{
The Effect of Drying Temperature and Time on Antioxidant Activity and Sensory Properties of Herbal Tea \\ Bag of Rambusa Leaf (Passiflora foetida L.) \\ ${ }^{1}$ Anabella Nadia Nathaniel, ${ }^{2}$ I Nengah Kencana Putra*, ${ }^{2}$ A. A. I. Sri Wiadnyani \\ ${ }^{1}$ Mahasiswa Program Studi Ilmu dan Teknologi Pangan, Fakultas Teknologi Pertanian, Universitas Udayana \\ ${ }^{2}$ Dosen Program Studi Ilmu dan Teknologi Pangan, Fakultas Teknologi Pertanian, Universitas Udayana \\ Kampus Bukit Jimbaran, Badung-Bali
}

\begin{abstract}
This research aimed to determine the effect of drying temperature and time on antioxidant activity and sensory properties of herbal tea bag of rambusa leaf and to obtain the optimum temperature and drying time that can produce rambusa leaf herbal tea bag with the highest antioxidant activity and the best sensory properties. This research used a completely randomized factorial design with two treatments namely, drying temperature $\left(40^{\circ} \mathrm{C}, 50^{\circ} \mathrm{C}, 60^{\circ} \mathrm{C}\right)$ and drying time ( 3 hours, 3.5 hours, 4 hours). There were 9 factorial combinations, each combination was repeated 2 times. The data obtained were analyzed by analysis of variance. If the treatment had a significant effect, it would be followed by the Duncan test. The results showed that the drying temperature and time treatment had a significant effect $(\mathrm{P}<0.05)$ on antioxidant activity, total phenols, total flavonoids, total tannins, water content, color (scoring test), and taste (scoring test), but no significant effect ( $P>0.05$ ) on the extract content in water, color (hedonic test), taste (hedonic test), and overall acceptance. The results showed that drying temperature of $60^{\circ} \mathrm{C}$ with a drying time of 3 hours had an optimum drying temperature and time to produce herbal tea bag of rambusa leaf with antioxidant activity of $46.28 \%$, total phenol level of $4.14 \mathrm{mg} \mathrm{GAE} / \mathrm{g}$, total flavonoids content of $26.48 \mathrm{mg} \mathrm{QE} / \mathrm{g}$, total tannin content of $6.23 \mathrm{mg} \mathrm{TAE} / \mathrm{g}$, water content of $8.38 \%$, extract content in water of $31.96 \%$, and sensory properties of yellow color and slight liked, bitter slightly taste and slight liked, and overall acceptance neutral.
\end{abstract}

Keywords: antioxidant, drying temperature and time, herbal tea bag, rambusa

\section{PENDAHULUAN}

Rambusa (Passiflora foetida L.) merupakan salah satu jenis tanaman liar yang banyak ditemukan merambat pada tanaman lain. Tanaman ini ditemukan di daerah berair seperti rawa dan sungai (Lim, 2012). Bagian tanaman rambusa memiliki potensi sebagai antioksidan (Lim, 2012). Tanaman rambusa terdiri dari beberapa bagian yaitu daun, bunga, dan buah. Daun rambusa merupakan salah satu alternatif pengobatan beberapa penyakit seperti inflamasi, rematik, diare dan sakit perut (Assadujjaman et al., 2014).

Pengolahan daun rambusa sebagai pangan masih belum banyak ditemukan karena keterbatasan informasi mengenai tanaman rambusa sehingga masyarakat belum mengetahui potensi pada tanaman ini. Menurut Lim (2012) daun rambusa dapat dikonsumsi sebagai sup dan lalapan di Indonesia dan minuman herbal di Vietnam. Salah satu alternatif yang dapat dilakukan untuk mengolah daun rambusa adalah mengolahnya menjadi teh herbal. Menurut Winarsi (2011) teh herbal merupakan minuman yang tidak berasal dari tanaman daun teh (Camellia sinensis). Teh herbal umumnya berasal dari satu atau campuran beberapa bahan yang terbuat dari kombinasi daun kering, biji, kayu, buah, bunga dan tanaman lain yang memiliki manfaat (Ravikumar, 2014).

Pengolahan daun rambusa menjadi teh herbal dapat dilakukan dengan pengeringan. Salah satu metode pengeringan yang dapat digunakan yaitu pengeringan dengan oven (oven drying). Keunggulan pengeringan dengan menggunakan oven adalah kondisi pengeringan yang dapat diatur. Suhu dan waktu merupakan faktor penting yang diperhatikan pada pengeringan. Andarwulan et al., (1996) menyatakan bahwa pemanasan dengan waktu yang cukup lama serta menggunakan suhu yang tinggi dapat menurunkan aktivitas antioksidan, sedangkan pengeringan dengan suhu yang rendah disertai waktu yang singkat akan menyebabkan aktivitas antioksidan 
yang didapatkan tidak maksimal. Hal ini dikarenakan kadar air yang terkandung pada bahan masih tinggi sehingga enzim polifenol oksidase masih aktif untuk melakukan proses oksidasi.

Penelitian Anggorowati et al. (2016) mengatakan bahwa daun alpukat pada suhu pengeringan $40^{\circ} \mathrm{C}$ dengan waktu 30 menit menghasilkan teh herbal daun alpukat dengan aktivitas antioksidan tertinggi berdasarkan $\mathrm{IC}_{50}$ sebesar 24,863 ppm, penelitian Adri dan Hersoelistyorini (2013) melaporkan bahwa pengeringan daun sirsak pada suhu $50^{\circ} \mathrm{C}$ dengan lama pengeringan 150 menit menghasilkan teh daun sirsak terbaik dengan aktivitas antioksidan tertinggi sebesar 76,06\%, sedangkan hasil penelitian Patin et al. (2018) menunjukkan bahwa pengeringan daun sambiloto pada suhu $60^{\circ} \mathrm{C}$ dengan lama pengeringan 60 menit menghasilkan teh daun sambiloto terbaik dengan aktivitas antioksidan sebesar 78,29\%. Rusnayanti et al. (2018) melaporkan bahwa semakin tinggi suhu pengeringan dan lamanya waktu pengeringan akan membuat warna teh hijau daun kakao akan semakin menurun. Saragih (2014) juga menyatakan bahwa semakin lama waktu pengeringan akan menyebabkan rasa sepat teh herbal daun torbangun semakin berkurang.

Dalam era-modernisasi seperti saat ini, masyarakat memiliki kecenderungan untuk memilih produk yang instan, salah satu contohnya adalah penyeduhan teh dalam bentuk celup. Penyeduhan teh dalam bentuk bubuk dinilai kurang efisien karena dibutuhkannya proses penyaringan sehingga produsen teh berinovasi untuk membuat minuman teh tanpa dilakukan penyaringan, seperti teh celup. Cara penyeduhan teh celup yang praktis membuat teh celup lebih diminati oleh masyarakat.

Penelitian ini bertujuan untuk mengetahui pengaruh suhu dan waktu pengeringan terhadap aktivitas antioksidan dan sifat sensoris teh herbal celup daun rambusa serta mendapatkan suhu dan waktu pengeringan terbaik yang dapat menghasilkan teh herbal celup daun rambusa dengan aktivitas antioksidan tertinggi dan sifat sensoris terbaik. Informasi mengenai pengaruh suhu dan waktu pengeringan dalam pembuatan teh herbal celup daun rambusa masih terbatas. Oleh karena itu, dalam penelitian ini diteliti pengaruh suhu dan waktu pengeringan terhadap aktivitas antioksidan dan sifat sensoris teh herbal celup daun rambusa.

\section{METODE PENELITIAN}

\section{Tempat dan Waktu}

Penelitian ini dilaksanakan di Laboratorium Analisis Pangan, Laboratorium Pengolahan Pangan, dan Laboratorium Mikrobiologi Pangan, Fakultas Teknologi Pertanian Universitas Udayana. Penelitian ini dilakukan pada bulan Juni 2019 hingga Agustus 2019.

\section{Bahan dan Alat}

Bahan yang digunakan dalam penelitian ini mencakup bahan utama dan bahan kimia. Bahan utama pada penelitian ini adalah daun rambusa (Passiflora foetida L.) yang tumbuh liar di sekitar Perumahan Bumi Jimbaran Asri, Bukit Jimbaran, Bali. Bahan kimia yang digunakan terdiri dari DPPH, reagen folin-ciocalteau, etanol, akuades, asam tanat, reagen follin denis, asam galat, $\mathrm{Na}_{2} \mathrm{CO}_{3}, \mathrm{AlCl}_{3}, \mathrm{NaOH}, \mathrm{NaNO}_{2}$, dan kuersetin.

Alat-alat yang digunakan dalam penelitian ini adalah oven, blender (Philips, Belanda), ayakan 40 mesh (Retsch, Jerman), kuas, alumunium foil, spektrofotometer (Genesys 10S UV-Vis, Amerika Serikat), rotary shaker, timbangan analitik (Shimadzu ATY224, Jerman), timbangan analitik (Sartorius MSA 2255-100-DU, Jerman), kertas Whatman No. 1, vortex (Barnstead Thermolyne, Iowa), pipet tetes, pipet mikro, tabung reaksi (Pyrex, Jepang), rak tabung reaksi, corong kaca (Pyrex, Jepang), corong plastik, labu ukur, gelas beaker (Pyrex, Jepang), erlenmeyer (Pyrex, Jepang), tabung sentrifugasi, alat sentrifugasi (Damon IEC Division, Amerika Serikat), botol amber, cawan alumunium, pinset, spatula, soxlet (Sybron), cawan porselin, kuvet, dan desikator.

\section{Pelaksanaan Penelitian Persiapan Sampel}

Daun rambusa disiapkan kemudian disortir untuk dihilangkan batangnya. Daun yang digunakan merupakan daun yang berwarna hijau muda, berukuran sedang, diambil pada bagian ujung hingga pertengahan, dan tidak memiliki bintik kuning atau putih di permukaannya. Daun yang telah disortir lalu dicuci dengan air mengalir 
untuk membersihkan debu atau kotoran yang menempel pada permukaan kulit.

\section{Pembuatan Bubuk Teh Herbal Celup}

Daun rambusa yang sudah dicuci kemudian dikeringkan dalam oven dengan suhu pengeringan $40^{\circ} \mathrm{C}, 50^{\circ} \mathrm{C}, 60^{\circ} \mathrm{C}$ dan waktu pengeringan selama 3 jam, 3,5 jam, dan 4 jam. Daun rambusa yang sudah dikeringkan kemudian dihancurkan dengan blender dan diayak menggunakan ayakan 40 mesh hingga menghasilkan bubuk teh herbal celup daun rambusa. Bubuk teh ditimbang sebanyak $\pm 2 \mathrm{~g}$ kemudian dimasukkan ke dalam teh celup berukuran $6,25 \times 5 \mathrm{~cm}$ sehingga dihasilkan teh herbal celup daun rambusa. Bubuk teh kemudian diuji pada kadar air, kadar ekstrak dalam air, total fenol, total flavonoid, total tanin, dan aktivitas antioksidan (Fatanah et al., 2016 dengan modifikasi).

\section{Pembuatan Minuman Teh Herbal Celup}

Teh herbal celup daun rambusa diseduh dengan $200 \mathrm{~mL}$ air bersuhu $100^{\circ} \mathrm{C}$ selama 3 menit dengan digerakkan naik turun dalam air sebanyak 5 kali. Kantong teh celup dikeluarkan dan dihasilkan minuman teh herbal celup daun rambusa. Hasil seduhan diuji secara sensoris (rasa, warna, penerimaan keseluruhan) (Horzic et al., 2009).

\section{Rancangan Penelitian dan Analisis Data}

Rancangan yang digunakan pada penelitian ini adalah Rancangan Acak Lengkap (RAL) Pola Faktorial dengan perlakuan suhu dan waktu pengeringan. Faktor pertama yaitu suhu pengeringan (S) yang terdiri dari 3 taraf: $\mathrm{S} 1$ (suhu pengeringan $40^{\circ} \mathrm{C}$ ), $\mathrm{S} 2$ (suhu pengeringan $50^{\circ} \mathrm{C}$ ), dan S3 (suhu pengeringan $60^{\circ} \mathrm{C}$ ). Faktor kedua yaitu waktu pengeringan (W) yang terdiri dari 3 taraf: W1 (waktu pengeringan 3 jam), W2 (waktu pengeringan 3,5 jam), dan W3 (waktu pengeringan 4 jam). Perlakuan ini diulang sebanyak dua kali sehingga diperoleh 18 unit percobaan.

Data yang diperoleh dianalisis dengan sidik ragam, apabila perlakuan berpengaruh akan dilanjutkan dengan uji Duncan (Steel dan Torrie, 1993).

\section{Parameter yang Diamati}

Parameter yang diamati dalam penelitian ini adalah kadar air menggunakan metode pengeringan (Sudarmadji et al., 1997), kadar ekstrak dalam air (SNI 3836:2013), kadar total fenol menggunakan metode spektrofotometri (Sakanaka et al., 2003), kadar total flavonoid menggunakan metode spektrofotometri (Xu dan Chang, 2007), kadar total tanin menggunakan metode spektrofotometri (Suhardi, 1997), aktivitas antioksidan $\left(\mathrm{IC}_{50}\right)$ menggunakan metode DPPH (Shah dan Modi, 2015), sifat organoleptik (Soekarto, 1985).

\section{HASIL DAN PEMBAHASAN}

\section{Kadar Air}

Hasil penelitian pengaruh suhu dan waktu pengeringan pada teh herbal celup daun rambusa terhadap kadar air dapat dilihat pada Tabel 1.

Hasil sidik ragam menunjukkan bahwa interaksi antara suhu dan waktu pengeringan berpengaruh nyata $(\mathrm{P}<0,05)$ terhadap kadar air teh herbal celup daun rambusa. Tabel 1 menunjukkan bahwa kadar air teh herbal daun rambusa berkisar antara 7,94\%-9,8\%. Kadar air tertinggi diperoleh pada perlakuan suhu pengeringan $40^{\circ} \mathrm{C}$ dengan waktu 3 jam yaitu 9,8\%, sedangkan kadar air terendah diperoleh pada perlakuan suhu pengeringan $60^{\circ} \mathrm{C}$ dengan waktu 4 jam yaitu $7,94 \%$. Hal ini menunjukkan bahwa semakin tinggi suhu pengeringan dan lama waktu pengeringan maka semakin rendah kadar air yang dihasilkan.

Taib et al., (1997) mengatakan bahwa hal ini terjadi karena meningkatnya kemampuan suatu bahan untuk melepaskan air dari permukaannya seiring dengan meningkatnya suhu udara pengering. Tidak hanya peningkatan suhu pengeringan, tetapi juga semakin lama waktu pengeringan yang diberikan akan membuat panas yang diterima bahan akan semakin banyak sehingga jumlah air yang diuapkan pada bahan pangan semakin banyak dan mengakibatkan kadar air semakin rendah (Winarno, 1995). Berdasarkan standar kadar air pada simplisia yaitu maksimal $10 \%$, kadar air pada teh herbal celup daun rambusa pada semua perlakuan telah memenuhi standar yang telah ditetapkan. 
Tabel 1. Nilai rata-rata kadar air (\%) teh herbal celup daun rambusa dengan perlakuan suhu dan waktu pengeringan

Waktu Pengeringan (Jam)

Suhu Pengeringan $\left({ }^{\circ} \mathrm{C}\right)$

\begin{tabular}{cccc}
\cline { 2 - 4 }$(\mathrm{Jam})$ & 40 & 50 & 60 \\
\hline \multirow{2}{*}{3} & $9,80 \pm 0,03 \mathrm{~A}$ & $8,78 \pm 0,04 \mathrm{~B}$ & $8,38 \pm 0,06 \mathrm{C}$ \\
& $\mathrm{a}$ & $\mathrm{a}$ & $\mathrm{a}$ \\
3,5 & $9,05 \pm 0,06 \mathrm{~A}$ & $8,70 \pm 0,03 \mathrm{~B}$ & $8,26 \pm 0,004 \mathrm{C}$ \\
& $\mathrm{b}$ & $\mathrm{a}$ & $\mathrm{a}$ \\
4 & $8,80 \pm 0,09 \mathrm{~A}$ & $8,52 \pm 0,004 \mathrm{~B}$ & $7,94 \pm 0,09 \mathrm{C}$ \\
& $\mathrm{c}$ & $\mathrm{b}$ & $\mathrm{b}$ \\
\hline
\end{tabular}

Keterangan: Nilai rata-rata \pm standar deviasi $(\mathrm{n}=2)$. Huruf yang sama pada baris dan kolom yang sama menunjukkan perlakuan tidak berbeda nyata $(\mathrm{P}>0,05)$. Notasi huruf dibelakang nilai rata-rata dilihat per baris sedangkan notasi huruf di bawah nilai rata-rata dilihat per kolom.

\section{Kadar Ekstrak Dalam Air}

Hasil penelitian mengenai pengaruh suhu dan waktu pengeringan pada teh herbal celup daun rambusa terhadap total kadar ekstrak dalam air dapat dilihat pada Tabel 2 .

Hasil sidik ragam menunjukkan bahwa interaksi antara suhu dan waktu pengeringan berpengaruh tidak nyata $(\mathrm{P}>0,05)$, sedangkan perlakuan suhu pengeringan berpengaruh nyata terhadap kadar ekstrak dalam air teh herbal celup daun rambusa. Tabel 2 menunjukkan kadar ekstrak dalam air teh herbal celup daun rambusa berkisar antara 30,17\%-34,33\%.

Kadar ekstrak dalam air tertinggi diperoleh pada suhu $60^{\circ} \mathrm{C}$ sebesar $34,33 \%$ yang tidak berbeda dengan waktu pengeringan $3,3,5$, dan 4 jam sedangkan kadar ekstrak dalam air terendah diperoleh pada suhu $40^{\circ} \mathrm{C}$ sebesar $30,17 \%$.

Semakin tinggi suhu pengeringan yang digunakan, semakin tinggi ekstrak dalam air yang dihasilkan. Hal ini diduga penggunaan suhu yang terlalu tinggi akan menyebabkan kadar air pada suatu bahan rendah yang mengakibatkan sifat bubuk menjadi semakin higroskopis sehingga kelarutan bubuk menjadi lebih besar. Hal ini sejalan dengan penelitian Satriadi et al., (2014) yang menyatakan suhu pengeringan yang rendah akan membuat kadar ekstrak dalam air teh kulit lidah buaya mengalami kerusakan, sedangkan suhu pengeringan yang tinggi akan menghasilkan kadar ekstrak dalam air yang lebih baik.

Tabel 2. Nilai rata-rata kadar ekstrak dalam air (\%) teh herbal celup daun rambusa dengan perlakuan suhu dan waktu pengeringan

\begin{tabular}{ccccc}
\hline \multirow{2}{*}{$\begin{array}{c}\text { Waktu Pengeringan } \\
(\mathrm{Jam})\end{array}$} & 40 & 50 & 60 & Rata-rata (waktu) \\
\cline { 2 - 4 } 3 & $29,85 \pm 0,21$ & $31,94 \pm 0,10$ & $33,99 \pm 0,40$ & $31,96 \mathrm{a}$ \\
3,5 & $30,22 \pm 0,93$ & $32,37 \pm 0,67$ & $34,48 \pm 0,16$ & $32,36 \mathrm{a}$ \\
4 & $30,43 \pm 0,75$ & $32,71 \pm 0,26$ & $34,50 \pm 0,19$ & $32,55 \mathrm{a}$ \\
\hline Rata-rata (suhu) & $30,17 \mathrm{c}$ & $32,38 \mathrm{~b}$ & $34,33 \mathrm{a}$ & \\
\hline
\end{tabular}

Keterangan: Nilai rata-rata \pm standar deviasi $(n=2)$. Huruf yang sama pada baris dan kolom yang sama menunjukkan perlakuan tidak berbeda nyata $(\mathrm{P}>0,05)$. Notasi huruf dibelakang nilai rata-rata dilihat per baris sedangkan notasi huruf di bawah nilai rata-rata dilihat per kolom.

\section{Kadar Total Fenol}

Hasil penelitian mengenai pengaruh suhu dan waktu pengeringan pada teh herbal celup daun rambusa terhadap kadar total fenol dapat dilihat pada Tabel 3. Hasil sidik ragam menunjukkan bahwa interaksi antara suhu dan 
waktu pengeringan berpengaruh nyata $(\mathrm{P}<0,05)$ terhadap total fenol teh herbal celup daun rambusa. Tabel 3 menunjukkan bahwa total fenol pada teh herbal celup daun rambusa berkisar antara 3,23 mg GAE/g - 4,30\% mg GAE/g.

Tabel 3. Nilai rata-rata kadar total fenol (mg GAE/g) teh herbal celup daun rambusa dengan perlakuan suhu dan waktu pengeringan

\begin{tabular}{cccc}
\hline \multirow{2}{*}{$\begin{array}{c}\text { Waktu Pengeringan } \\
(\mathrm{Jam})\end{array}$} & \multicolumn{3}{c}{ Suhu Pengeringan $\left({ }^{\circ} \mathrm{C}\right)$} \\
\cline { 2 - 4 } 3 & 30 & 50 & 60 \\
\hline \multirow{2}{*}{3,5} & $\mathrm{~b}$ & $3,87 \pm 0,01 \mathrm{~B}$ & $4,14 \pm 0,04 \mathrm{~A}$ \\
& $3,75 \pm 0,03 \mathrm{~B}$ & $\mathrm{c}$ & $\mathrm{a}$ \\
& $\mathrm{a}$ & $4,10 \pm 0,03 \mathrm{~A}$ & $4,04 \pm 0,01 \mathrm{~A}$ \\
4 & $3,83 \pm 0,01 \mathrm{~B}$ & $\mathrm{~b}$ & $\mathrm{a}$ \\
& $\mathrm{a}$ & $4,30 \pm 0,04 \mathrm{~A}$ & $3,80 \pm 0,03 \mathrm{~B}$ \\
& & $\mathrm{a}$ & $\mathrm{b}$ \\
\hline
\end{tabular}

Keterangan: Nilai rata-rata \pm standar deviasi $(n=2)$. Huruf yang sama pada baris dan kolom yang sama menunjukkan perlakuan tidak berbeda nyata $(\mathrm{P}>0,05)$. Notasi huruf dibelakang nilai rata-rata dilihat per baris sedangkan notasi huruf di bawah nilai rata-rata dilihat per kolom.

Total fenol tertinggi diperoleh pada perlakuan suhu pengeringan $50^{\circ} \mathrm{C}$ dengan waktu 4 jam yaitu 4,30 $\mathrm{mg}$ GAE/g yang tidak berbeda dengan perlakuan suhu $60^{\circ} \mathrm{C}$ dengan waktu 3 jam dan suhu $60^{\circ} \mathrm{C}$ dengan waktu 3,5 jam sedangkan total fenol terendah diperoleh pada suhu pengeringan $40^{\circ} \mathrm{C}$ dengan waktu 3 jam yaitu 3,23 $\mathrm{mg} \mathrm{GAE} / \mathrm{g}$. Hal ini diduga bahwa total fenol pada teh herbal celup daun rambusa optimum pada suhu pengeringan $50^{\circ} \mathrm{C}$ dengan waktu 4 jam dan turun setelah melewati suhu optimumnya. Rahmawati et al., (2013) mengatakan semakin tinggi suhu pengeringan dan lama waktu pengeringan maka semakin tinggi inaktivasi enzim polifenol oksidase sehingga aktivitas enzim akan semakin rendah, dan kerusakan fenol akan semakin kecil. Akan tetapi kandungan fenol juga akan terganggu oleh semakin tingginya suhu pengeringan sehingga jumlah total fenol akan mencapai puncak maksimum kemudian konstan dan cenderung mengalami penurunan.

\section{Kadar Total Flavonoid}

Hasil penelitian mengenai pengaruh suhu dan waktu pengeringan pada teh herbal celup daun rambusa terhadap kadar total flavonoid dapat dilihat pada Tabel 4. Hasil sidik ragam menunjukan bahwa interaksi antara suhu dan waktu pengeringan berpengaruh nyata $(\mathrm{P}<0,05)$ terhadap total flavonoid teh herbal celup daun rambusa. Berdasarkan Tabel 4, kadar total flavonoid teh herbal celup daun rambusa berkisar antara 22,28 mg QE/g-27,69 mg QE/g. Kadar total flavonoid tertinggi diperoleh pada perlakuan suhu pengeringan $50^{\circ} \mathrm{C}$ dengan waktu 4 jam yaitu $27,69 \mathrm{mg} \mathrm{QE} / \mathrm{g}$ yang tidak berbeda dengan perlakuan suhu $50^{\circ} \mathrm{C}$ dengan waktu 3,5 jam dan suhu $60^{\circ} \mathrm{C}$ dengan waktu 3 jam sedangkan kadar total flavonoid terendah diperoleh pada perlakuan suhu pengeringan $40^{\circ} \mathrm{C}$ dengan waktu 3 jam yaitu $22,28 \mathrm{mg}$ QE/g yang tidak berbeda dengan perlakuan suhu $40^{\circ} \mathrm{C}$ dengan waktu 3,5 jam.

Semakin tinggi suhu yang disertai waktu pemanasan yang semakin lama akan mengakibatkan senyawa metabolit sekunder yang berperan sebagai antioksidan (flavonoid) rusak. Penurunan makromolekul seperti flavonoid selama pemanasan dipengaruhi oleh suhu dan waktu yang digunakan (Zainol et al., 2009). Menurut Jeong et al., (2004), perlakuan pemanasan (suhu dan waktu pengeringan) dapat mengakibatkan keluarnya beberapa senyawa fenolik dengan berat molekul rendah, dimana flavonoid yang terdapat pada teh merupakan senyawa fenolik yang memiliki berat molekul rendah. 
Tabel 4. Nilai rata-rata kadar total flavonoid ( $\mathrm{mg} \mathrm{QE} / \mathrm{g}$ ) teh herbal celup daun rambusa dengan perlakuan suhu dan waktu pengeringan

\begin{tabular}{cccc}
\hline $\begin{array}{c}\text { Waktu Pengeringan } \\
(\mathrm{Jam})\end{array}$ & 40 & 50 & Suhu Pengeringan $\left({ }^{\circ} \mathrm{C}\right)$ \\
\cline { 2 - 4 } 3 & $22,28 \pm 0,55 \mathrm{~B}$ & $25,30 \pm 0,36 \mathrm{~A}$ & $26,48 \pm 0,54 \mathrm{~A}$ \\
& $\mathrm{~b}$ & $\mathrm{~b}$ & $\mathrm{a}$ \\
3,5 & $23,88 \pm 0,54 \mathrm{~B}$ & $26,62 \pm 0,74 \mathrm{~A}$ & $24,02 \pm 0,37 \mathrm{~B}$ \\
& $\mathrm{ab}$ & $\mathrm{ab}$ & $\mathrm{b}$ \\
4 & $24,54 \pm 0,74 \mathrm{~B}$ & $27,69 \pm 0,37 \mathrm{~A}$ & $22,80 \pm 0,55 \mathrm{~B}$ \\
& $\mathrm{a}$ & $\mathrm{a}$ & $\mathrm{b}$ \\
\hline
\end{tabular}

Keterangan: Nilai rata-rata \pm standar deviasi $(\mathrm{n}=2)$. Huruf yang sama pada baris dan kolom yang sama menunjukkan perlakuan tidak berbeda nyata $(\mathrm{P}>0,05)$. Notasi huruf dibelakang nilai rata-rata dilihat per baris sedangkan notasi huruf di bawah nilai rata-rata dilihat per kolom.

\section{Kadar Total Tanin}

Hasil penelitian pengaruh suhu dan waktu pengeringan pada teh herbal celup daun rambusa terhadap kadar total tanin dapat dilihat pada Tabel 5. Hasil sidik ragam menunjukan bahwa interaksi antara suhu dan waktu pengeringan berpengaruh nyata $(\mathrm{P}<0,05)$ terhadap kadar total tanin teh herbal celup daun rambusa. Berdasarkan Tabel 5,

Hal ini diduga suhu pengeringan yang tinggi dengan waktu yang terlalu lama akan menyebabkan tanin yang memiliki sifat tidak tahan panas akan mengalami kerusakan. Pada penelitian Ismanto et al., (2016), teh herbal kedondong mengalami peningkatan hingga suhu pengeringan $70^{\circ} \mathrm{C}$ dan mengalami penurunan pada suhu $80^{\circ} \mathrm{C}$. Hal ini dikarenakan pada daun teh mengandung enzim katekol oksidase yang dapat mengubah tanin menjadi turunannya. Pada proses kadar total tanin tertinggi diperoleh pada perlakuan suhu $50^{\circ} \mathrm{C}$ dengan waktu 4 jam yaitu $6,47 \mathrm{mg} \mathrm{TAE} / \mathrm{g}$ yang tidak berbeda dengan suhu $50^{\circ} \mathrm{C}$ dengan waktu 3,5 jam dan suhu $60^{\circ} \mathrm{C}$ dengan waktu 3 jam, sedangkan kadar total tanin terendah terdapat pada perlakuan suhu pengeringan $40^{\circ} \mathrm{C}$ selama yaitu $5,55 \mathrm{mg} \mathrm{TAE} / \mathrm{g}$. pembuatan teh hijau, (tanpa proses oksidasi enzimatis), dengan enzim katekol oksidase yang aktif, tanin yang terkandung di dalamnya tidak mengalami banyak perubahan dan tersimpan pada jaringan tanaman maka kadar total tanin (teh yang diproses tanpa oksidasi enzimatis) tetap tinggi karena sedikitnya terjadi oksidasi enzimatis (Hartoyo, 2003).

Tabel 5. Nilai rata-rata kadar total tanin (mg TAE/g) teh herbal celup daun rambusa dengan perlakuan suhu dan waktu pengeringan

\begin{tabular}{cccc}
\hline \multirow{2}{*}{ Waktu Pengeringan $(\mathrm{Jam})$} & \multicolumn{3}{c}{ Suhu Pengeringan $\left({ }^{\circ} \mathrm{C}\right)$} \\
\cline { 2 - 4 } 3 & 40 & 50 & 60 \\
\hline \multirow{2}{*}{3,5} & $5,55 \pm 0,07 \mathrm{C}$ & $5,91 \pm 0,01 \mathrm{~B}$ & $6,23 \pm 0,07 \mathrm{~A}$ \\
& $\mathrm{~b}$ & $\mathrm{~b}$ & $\mathrm{a}$ \\
4 & $5,71 \pm 0,09 \mathrm{~B}$ & $6,25 \pm 0,07 \mathrm{~A}$ & $6,10 \pm 0,02 \mathrm{~A}$ \\
& $\mathrm{ab}$ & $\mathrm{a}$ & $\mathrm{ab}$ \\
& $5,82 \pm 0,05 \mathrm{~B}$ & $6,47 \pm 0,13 \mathrm{~A}$ & $5,95 \pm 0,04 \mathrm{~B}$ \\
& $\mathrm{a}$ & $\mathrm{a}$ & $\mathrm{b}$ \\
\hline
\end{tabular}

Keterangan: Nilai rata-rata \pm standar deviasi $(\mathrm{n}=$

2). Huruf yang sama pada baris dan kolom yang sama menunjukkan perlakuan tidak berbeda nyata
$(\mathrm{P}>0,05)$. Notasi huruf dibelakang nilai rata-rata dilihat per baris sedangkan notasi huruf di bawah nilai rata-rata dilihat per kolom. 


\section{Aktivitas Antioksidan}

Hasil sidik ragam menunjukan bahwa interaksi antara suhu dan waktu pengeringan berpengaruh nyata $(\mathrm{P}<0,05)$ terhadap aktivitas antioksidan teh herbal celup daun rambusa, hal ini dapat dilihat pada Lampiran 6. Berdasarkan Tabel 10 dapat dilihat bahwa aktivitas antioksidan teh herbal celup daun rambusa berkisar antara 39,88\%-53,13\%. Aktivitas antioksidan tertinggi dihasilkan pada perlakuan suhu pengeringan $50^{\circ} \mathrm{C}$ selama 4 jam yaitu $53,13 \%$ yang tidak berbeda dengan suhu $60^{\circ} \mathrm{C}$ dengan waktu 3 jam, sedangkan aktivitas antioksidan terendah dihasilkan pada perlakuan suhu pengeringan $40^{\circ} \mathrm{C}$ selama 3 jam yaitu 39,88\%.

Tabel 6. Nilai rata-rata aktivitas antioksidan (\%) teh herbal celup daun rambusa dengan perlakuan suhu dan waktu pengeringan

\begin{tabular}{cccc}
\hline \multirow{2}{*}{$\begin{array}{c}\text { Waktu Pengeringan } \\
\text { (Jam) }\end{array}$} & 40 & 50 & Suhu Pengeringan $\left({ }^{\circ} \mathrm{C}\right)$ \\
\cline { 2 - 4 } & $39,88 \pm 0,84 \mathrm{~B}$ & $45,68 \pm 0,63 \mathrm{~A}$ & $46,28 \pm 0,66 \mathrm{~A}$ \\
& $\mathrm{~b}$ & $\mathrm{c}$ & $\mathrm{a}$ \\
& $42,86 \pm 0,42 \mathrm{~B}$ & $49,02 \pm 0,13 \mathrm{~A}$ & $43,16 \pm 0,79 \mathrm{~B}$ \\
3,5 & $\mathrm{a}$ & $\mathrm{b}$ & $\mathrm{b}$ \\
& $44,45 \pm 0,69 \mathrm{~B}$ & $53,13 \pm 0,21 \mathrm{~A}$ & $41,49 \pm 0,44 \mathrm{C}$ \\
4 & $\mathrm{a}$ & $\mathrm{a}$ & $\mathrm{b}$ \\
\hline
\end{tabular}

Keterangan: Nilai rata-rata \pm standar deviasi $(\mathrm{n}=2)$. Huruf yang sama pada baris dan kolom yang sama menunjukkan perlakuan tidak berbeda nyata $(\mathrm{P}>0,05)$. Notasi huruf dibelakang nilai rata-rata dilihat per baris sedangkan notasi huruf di bawah nilai rata-rata dilihat per kolom.

\section{Sifat Sensoris}

\section{Warna}

Warna merupakan salah satu faktor yang menentukan penilaian panelis terhadap suatu produk. Hasil sidik ragam menunjukkan bahwa perlakuan suhu dan waktu pengeringan berpengaruh nyata $(\mathrm{P}<0,05)$ terhadap warna the herbal celup daun rambusa yang dilakukan dengan uji skoring. Tabel 11 menunjukkan bahwa nilai rata-rata warna teh herbal celup daun rambusa dengan uji skoring tertinggi diperoleh pada perlakuan suhu pengeringan $50^{\circ} \mathrm{C}$ dengan waktu pengeringan 4 jam yaitu 3,90 dengan kriteria kuning kehijauan sedangkan nilai rata-rata terendah diperoleh pada perlakuan suhu pengeringan $40^{\circ} \mathrm{C}$ dengan waktu pengeringan 3 jam yaitu 2,35 dengan kriteria coklat kekuningan yang tidak berbeda dengan $40^{\circ} \mathrm{C}$ dengan waktu pengeringan 3,5 jam. Hal ini diduga karena semakin tinggi suhu disertai semakin lama waktu pengeringan akan membuat enzim polifenol oksidasi inaktif sehingga warna air seduhan masih memiliki warna kehijauan. Hermani dan Nurdjanah (2004) menyatakan bahwa pengeringan mengakibatkan warna hijau pada daun akan mengalami oksidasi menjadi coklat dikarenakan proses pencoklatan.

Hasil sidik ragam menunjukkan bahwa perlakuan suhu dan waktu pengeringan berpengaruh tidak nyata $(\mathrm{P}>0,05)$ terhadap warna teh herbal celup daun rambusa yang dilakukan dengan uji hedonik. Nilai rata-rata kesukaan panelis terhadap warna teh herbal daun rambusa berkisar antara 4,50 hingga 5,15 dengan kriteria agak suka. Hasil sidik ragam menunjukkan bahwa perlakuan suhu dan waktu pengeringan berpengaruh tidak nyata $(\mathrm{P}>0,05)$ terhadap warna 
teh herbal celup daun rambusa yang dilakukan dengan uji hedonik. Nilai rata-rata kesukaan panelis terhadap warna teh herbal celup daun rambusa berkisar antara 4,50 hingga 5,15 dengan kriteria agak suka.

\section{Rasa}

Hasil sidik ragam menunjukkan bahwa perlakuan suhu dan waktu pengeringan berpengaruh nyata $(\mathrm{P}<0,05)$ terhadap rasa teh herbal celup daun rambusa yang dilakukan dengan uji skoring. Tabel 11 menunjukkan bahwa nilai rata-rata rasa teh herbal celup daun rambusa dengan uji skoring tertinggi diperoleh pada perlakuan suhu pengeringan $60^{\circ} \mathrm{C}$ dengan waktu pengeringan 4 jam yaitu 3,10 dengan kriteria agak sepat sedangkan nilai rata-rata terendah diperoleh pada perlakuan suhu pengeringan $40^{\circ} \mathrm{C}$ dengan waktu pengeringan 3 jam yaitu 2,05 dengan kriteria sepat. Menurunnya rasa sepat diduga karena menurunnya kadar tanin dan polifenol seiring dengan tingginya suhu dan lamanya waktu pengeringan.

Hasil sidik ragam menunjukkan bahwa perlakuan suhu dan waktu pengeringan berpengaruh tidak nyata $(\mathrm{P}>0,05)$ terhadap rasa teh herbal celup daun rambusa yang dilakukan dengan uji hedonik. Nilai rata-rata uji hedonik terhadap rasa pada Tabel 11 menunjukkan panelis memberikan penilaian kesukaan yang berkisar antara 4,20 dengan kriteria biasa hingga 4,65 dengan kriteria agak suka.

\section{Penerimaan Keseluruhan}

Hasil sidik ragam menunjukkan bahwa perlakuan suhu dan waktu pengeringan berpengaruh tidak nyata $(\mathrm{P}>0,05)$ terhadap penerimaan keseluruhan teh herbal celup daun rambusa yang dilakukan dengan uji hedonik. Penerimaan keseluruhan merupakan penilaian terakhir yang merupakan hasil dari beberapa penilaian terhadap beberapa parameter seperti warna, aroma, dan rasa. Berdasarkan tabel 7, nilai rata-rata penilaian keseluruhan panelis terhadap teh herbal daun rambusa berkisar antara 4,20 dengan kriteria biasa hingga 4,78 dengan kriteria agak suka. Teh herbal celup daun rambusa secara keseluruhan dapat diterima oleh panelis.

Tabel 7. Nilai rata-rata sifat sensoris teh herbal celup daun rambusa dengan perlakuan suhu dan waktu pengeringan

\begin{tabular}{cccccc}
\hline \multirow{2}{*}{ Perlakuan } & \multicolumn{5}{c}{ Nilai Rata-rata } \\
\cline { 2 - 6 } & \multicolumn{2}{c}{ Warna } & \multicolumn{2}{c}{ Rasa } & $\begin{array}{c}\text { Penerimaan } \\
\text { Keseluruhan }\end{array}$ \\
\cline { 2 - 6 } & $2,35 \pm 0,49 \mathrm{e}$ & $5,15 \pm 1,18 \mathrm{a}$ & $2,05 \pm 1,15 \mathrm{a}$ & $4,60 \pm 1,09 \mathrm{a}$ & $4,60 \pm 1,23 \mathrm{a}$ \\
S1W1 & $2,55 \pm 0,51 \mathrm{de}$ & $5,05 \pm 1,19 \mathrm{a}$ & $2,85 \pm 1,18 \mathrm{~b}$ & $4,65 \pm 1,23 \mathrm{a}$ & $4,75 \pm 1,21 \mathrm{a}$ \\
S1W2 & $2,85 \pm 0,49 \mathrm{~cd}$ & $4,95 \pm 1,19 \mathrm{a}$ & $2,85 \pm 1,18 \mathrm{~b}$ & $4,35 \pm 1,23 \mathrm{a}$ & $4,40 \pm 1,31 \mathrm{a}$ \\
S1W3 & $2,90 \pm 0,64 \mathrm{~cd}$ & $5,05 \pm 0,88 \mathrm{a}$ & $2,75 \pm 1,33 \mathrm{~b}$ & $4,40 \pm 1,31 \mathrm{a}$ & $4,20 \pm 1,44 \mathrm{a}$ \\
S2W1 & $3,40 \pm 0,75 \mathrm{~b}$ & $4,75 \pm 1,41 \mathrm{a}$ & $2,85 \pm 1,27 \mathrm{~b}$ & $4,55 \pm 1,10 \mathrm{a}$ & $4,45 \pm 1,10 \mathrm{a}$ \\
S2W2 & $3,90 \pm 0,91 \mathrm{a}$ & $5,05 \pm 1,14 \mathrm{a}$ & $2,90 \pm 1,02 \mathrm{~b}$ & $4,60 \pm 1,05 \mathrm{a}$ & $4,60 \pm 1,18 \mathrm{a}$ \\
S2W3 & $2,95 \pm 0,69 \mathrm{~cd}$ & $4,50 \pm 1,54 \mathrm{a}$ & $2,75 \pm 1,07 \mathrm{~b}$ & $4,40 \pm 1,23 \mathrm{a}$ & $4,50 \pm 1,19 \mathrm{a}$ \\
S3W1 & $3,40 \pm 0,99 \mathrm{~b}$ & $4,75 \pm 1,15 \mathrm{a}$ & $2,90 \pm 1,10 \mathrm{~b}$ & $4,45 \pm 1,10 \mathrm{a}$ & $4,40 \pm 1,23 \mathrm{a}$ \\
S3W2 & $3,10 \pm 0,55 \mathrm{bc}$ & $5,05 \pm 1,01 \mathrm{a}$ & $3,10 \pm 1,02 \mathrm{~b}$ & $4,20 \pm 1,28 \mathrm{a}$ & $4,25 \pm 1,16 \mathrm{a}$ \\
S3W3 & & &
\end{tabular}

Keterangan: Kriteria skoring warna: 1 (coklat); 2 (coklat kekuningan); 3 (kuning); 4 (kuning kehijauan); 5 (hijau). Kriteria skoring rasa: 1 (sangat sepat); 2 (sepat); 3 (agak sepat); 4 (sedikit sepat); 5 (tidak sepat). Kriteria hedonik: 1(sangat tidak suka); 2 (tidak suka); 3(agak tidak suka); 4 (biasa); 5(agak suka); 6(suka); 7(sangat suka).

\section{KESIMPULAN DAN SARAN}

\section{Kesimpulan}

Berdasarkan hasil penelitian dapat disimpulkan hal-hal sebagai berikut:
1. Suhu dan waktu pengeringan berpengaruh nyata terhadap kadar air, kadar total fenol, kadar total flavonoid, kadar total tanin, aktivitas antioksidan, warna (uji skoring), dan 
rasa (uji skoring), sedangkan berpengaruh tidak nyata terhadap warna (uji hedonik), rasa (uji hedonik) dan penerimaan keseluruhan (uji hedonik) teh herbal celup daun rambusa.

2. Suhu pengeringan $60^{\circ} \mathrm{C}$ dengan waktu pengeringan 3 jam merupakan suhu dan waktu pengeringan terbaik untuk menghasilkan teh herbal celup daun rambusa dengan aktivitas antioksidan tertinggi dengan nilai $46,28 \%$, memiliki kadar total fenol 4,14 mg GAE/g, kadar total flavonoid $26,48 \mathrm{mg}$ QE/g, kadar total tanin 6,23 mg TAE/g, kadar air 8,38\%, kadar ekstrak dalam air $31,96 \%$, dan sifat sensoris dengan warna (kuning, agak suka), rasa (agak sepat, agak suka), dan penerimaan keseluruhan (biasa).

\section{Saran}

Berdasarkan hasil penelitian, disarankan menggunakan suhu pengeringan $60^{\circ} \mathrm{C}$ dengan waktu 3 jam untuk membuat teh herbal celup daun rambusa. Perlu dilakukan penelitian lebih lanjut terkait suhu dan waktu penyeduhan terhadap aktivitas antioksidan teh herbal celup daun rambusa.

\section{DAFTAR PUSTAKA}

Adri, D. dan W. Hersoelistyorini. 2013. Aktivitas antioksidan dan sifat organoleptik teh daun sirsak (Annona muricata L.) berdasarkan lama pengeringan. Jurnal Pangan dan Gizi, 4(7):2-34.

Agusman, A. 2013. Pengujian Organoleptik Teknologi Pangan. Universitas Muhammadiyah Semarang, Semarang.

Ahadi, M. R. 2003. Kandungan Tanin Terkondensasi dan Laju Dekomposisi pada Serasah Daun Rhizospora mucronata Lamk pada Ekosistem Tambak Tumpangsari, Purwakarta, Jawa Barat. Dipublikasikan. Skripsi. Institut Pertanian Bogor, Bogor.

Aisyiatussupriana, S., A. Alamsyah, dan Y. Sulastri. 2018. Pengaruh lama pengeringan terhadap beberapa komponen mutu teh kulit melinjo (Gnetum gnemon L.). Diakses tanggal: 10 November 2019.
Amela, M.T. dan P.S. Hoc. 1998. Biología floral de Pasiflora foetida (Passifloraceae). Rev. Biol.Trop. 46:191-202.

Andarwulan, N., C.H. Wijaya, dan D.T. Cahyono. 1996. Aktivitas antioksidan dari daun sirih (Piper betle L.). Bul.Teknologi dan Industri Pangan. 7:29-37.

Anggorowati, D. A., G. Priandini, dan Thufail. 2016. Potensi daun alpukat (Persea americana Miller) sebagai minuman teh herbal yang kaya akan antioksidan. Industri Inovatif. 6(1):1-7.

Angraiyati, D. dan F. Hamzah. 2017. Lama pengeringan pada pembuatan teh herbal daun pandan wangi (Pandanus amarylifolius Roxb.,) terhadap aktivitas antioksidan. JOM Faperta UR. 4(1):1-12.

Anonimus. 1985. Cara Pembuatan Simplisia. Dirjen Pengawasan Obat dan Makanan. Jakarta.

Anonimus. 2013. SNI 3836:2013. Teh Kering dalam Kemasan. Badan Standarisasi Nasional. Jakarta.

Asir, P. Joseph, S. Hemmalakshmi, S. Priyanga, dan K. Devaki. 2014. In vitro free radical scavenging activity and secondary metabolites in Passiflora foetida $\mathrm{L}$. Department of Biochemistry, Karpagam University, Coimbatore, India. Asian J Pharmaceut Res Health Care. 6.

Assadujjaman, Md., A. Mishuk, Md. A. Hossain, dan U. Karmakar. 2014. Medicinal potential of Passiflora foetida L. Plant Extracts: Biological and Pharmacological Activities. Journal of Integrative Medicine. 12(2): 121126.

Azis, R. dan I. R. Akolo. 2019. Kandungan antioksidan dan kadar air pada teh Daun mangga quini (Mangifera indica). Journal of Agritech Science. 3(1):1-9.

Buckle, K. A., R. A. Edwards, G. H. Fleet, dan M. Wootton. 1987. Ilmu Pangan. Terjemahan, H. Purnomo dan Adiono. UI-Press, Jakarta. 
Chen C.W., Ho C.T.,1995. Antioxidant properties of polyphenols extracted green and black teas. J. Food Lipids. 2:35-46.

Cronquist, A. 1981. An Integrated System of Classification of Flowering Plants. Columbia University Press, New York.

Cuong, R.V., Ling, L.H., Quan, G.K., Tiep, T.D., Nan, X., Qing, C.X., Lin, T.L. 2014. Effect of roasting conditions on several chemical constituents of vietnam robusta coffee. Food Technology 38(2):43-56.

Daniel, M. 2006. Medicinal Plants Chemistry and Properties. Science Publisher.Enfield, NH, USA.

Daroini, O. 2006. Kajian Proses Pembuatan Teh Herbal dari Campuran Teh Hijau (Camellia sinensis), Rimpang Bangle (Zingiber cassumumar Roxb.) dan Daun Cermai (Phyllanthus acidus (L.) Skeels). Skripsi. Tidak dipublikasikan. Fakultas Pertanian Institut Pertanian Bogor, Bogor.

Dhawan, K., S. Dhawan, dan A. Sharma. 2004. Passiflora: a review update, J. Ethnopharmacol, 94: 1-23.

Desmiaty, Y. H. Ratih, M.A. Dewi, dan R. Agustin. 2008. Penentuan jumlah tanin total pada daun jati belanda (Guazuma ulmifolia Lamk) dan daun sambang darah (Excoecaria bicolor Hassk.) secara kolorimetri dengan pereaksi biru prusia. Ortocarpus. 8:106-109.

Dewi, N.W.O.A.C., N.M. Puspawati., I.M.D. Swantara., I.A.R.A. Asih. dan W.S. Rita. 2014. Aktivitas antioksidan senyawa flavonoid ekstrak etanol biji terong belanda (Solanum betaceum, syn) dalam menghambat reaksi peroksidasi lemak pada plasma darah tikus wistar. Cakra Kimia (Indonesian E- Journal of Applied Chemistry). 2(1): 7-16.

Effendi, S. 2009. Teknologi Pengolahan dan Pengawetan Pangan. Alfabeta, Bandung.

Egwuche, R. U., A. A. Odetola, dan O. L. Erukainure. 2011. Preliminary investigation into the chemical properties of Peperomia pellucida L. Research Journal of Phytochemistry. 5(1): 48-53.

Fatanah, D. N., N. Abdullah, N. Hashim, dan A. A. Hamid. 2016. Antioxidant activity, colour, and mineral content of herbal tea prepared from Cosmos caudatus leaves at different maturity stages. Malaysian Journal of Analytical Sciences. 20(3):607-617.

Fitriana, A., N. Harun, dan Yusmarini. 2017. Mutu teh herbal daun keji beling dengan perlakuan lama pengeringan. Agricultural Science and Technology Journal. 16(2): 3441.

George, M. 2017. Qualitative \& quantitative phytochemical analysis on the leaves \& fruits of Pasiflora foetida. International Journal of Pharmaceutical Science Invention. 6(2): 2319-6718

Hambali, E., M. Z. Nasution dan E. Herliana. 2005. Membuat Aneka Herbal Tea. Penebar Swadaya, Jakarta.

Harborne, J. B. 1987. Metode Fitokimia. Penuntun Cara Modern Menganalisis Tumbuhan. Penerjemah: Kokasih Padmawinata, dan Iwang Sooediro. Edisi 2. Institut Teknologi Bandung, Bandung. Halaman 102-103, 147149, 234.

Hartoyo, A. 2003. Teh dan Khasiatnya bagi Kesehatan. Kanisius, Yogyakarta.

Hasibuan, R. 2005. Proses Pengeringan. Fakultas Teknik Kimia Universitas Sumatera Utara, Medan.

Hely, E., M. A. Zaini, dan A. Alamsyah. 2018. Pengaruh lama pengeringan terhadap sifat fisiko kimia teh daun kersen (Muntingia calabura L.). Jurnal Agrotek. 5(1):1-9.

Hermani dan R. Nurdjanah. 2004. Aspek pengeringan dalam mempertahankan kandungan metabolit sekunder pada tanaman obat. Jurnal Perkembangan Teknologi Tro. 21(2):15-21.

Hernawan, U.E. dan A.D. Setyawan. 2003. Review: Senyawa organosulfur bawang 
putih (Allium sativum L.) dan aktivitas biologinya. Biofarmasi. 1(2): 65-76.

Horzic, D., D. Komes, A. Belscak, K. K. Ganic, D. Ivekovic, dan D. Karlovic. 2009. The composition of polyphenols and methylxanthines in teas and herbal infusions. Food Chemistry. 115:441-448.

Hikmah, A.F., S.A. Budhiyanti, dan N. Ekantari. 2009. Pengaruh pengeringan terhadap aktivitas antioksidan Spirulina platensis. Prosiding Seminar Nasional Tahunan VI Hasil Penelitian Perikanan dan Kelautan. 4: $1-11$.

Hughes, K.V. dan B.J. Willenberg. 1994. Quality for Keeps: Drying food. University of Missouri, Missouri.

Ismanto, S. D., I. D. Rahmi, dan A. Febriani. 2016. The influence of drying temperature on chemical components of herbal tea leaves (Spondias Dulcis, Soland).

Jahangiri, Y., H. Ghahremani, J. A. Torghabeh, dan E. A. Salehi. 2011. Effect of temperature and solvent on the total phenolic compounds extraction from leaves of Ficus carica. Journal of Chemical and Pharmaceutical Research. 3(5):253-259.

Jeong, S. M., S.Y Kim., D. R. Kim., S.C. Jo., K.C. Nam., D.U. Ahn., dan S.C. Lee. 2004. Effect of heat treatment on the antioxidant activity of extracts from citrus peels. JAgric. Food Chem. 52:3389-3393.

Kumar, V., R. S. Cotran, dan S. L. Robbins. 2007. Robbins Buku Ajar Patologi Edisi ke-7. EGC, Jakarta.

Lim, T. K. 2012. Edible Medical and NonMedical Plant. London New York: Springer Dordrecht Heidelberg. 879-880.

Makkar, H. P. S. 1993. Antinutritional Factor in Food for Livestock in Animal Producting in Developing Country. British Society of Animal Production.

Maldonado, R. A. P. 1994. The Chemical Nature and Biologycal Activity of Tannins in Forages Legumes Fed to Sheep and Goat.
Thesis. Published. Departement of Agriculture Australia University of Quensland Australia, Australia.

Meilgaard, M. 2000. Teknologi Pangan. Graha Ilmu, Yogyakarta.

Nair, C. I., K. Jayachadran, dan S. Shasidar. 2008. Biodegradation of phenol. African Journal of Biotechnology.7:4951-4958.

Nasiru, N. 2014. Teknologi Pangan Teori Praktis dan Aplikasi. Graha Ilmu, Yogyakarta.

Patin, E. W., M. A. Zaini, dan Y. Sulastri. 2018. Pengaruh variasi suhu pengeringan terhadap sifat fisiko kimia teh daun sambiloto (Andrographis paniculata). Pro Food (Jurnal Ilmu dan Teknologi Pangan). 4(1):251-258.

Patras, A., N. P. Brunton, C. Donnell, B. K., dan Tiwari. 2009. Effect of Thermal Processing on Anthocyanin Stability in Foods; Mechanisms and Kinetics of Degradation. Trends in Food Science and Technology.

Purnomo, W., L. U. Khasanah, dan B. K. Anandito. 2016. Pengaruh ratio kombinasi maltodekstrin, karagenan, dan whey terhadap karakteristik mikroenkapsulan pewarna alami daun jati (Tectona grandis Lf). Jurnal Aplikasi Teknologi Pangan. 3(3).

Rahmawati, N., A. Fernando, dan Wachyuni. 2013. Kandungan fenolik dan aktivitas antioksidan ekstrak daun gambir kering (Uncaria gambir hunter roxb). J. Ind. Che. Acta. 4(1):1-6.

Ravikumar. 2014. Review on herbal teas. Journal of Pharmaceutical Sciences and Research. 6(5):236-238.

Reynertson, K. A. 2007. Phytochemical Analysis of Bioactive Constituens from Edible Myrtaceae Fruit. Disertasi. Tidak dipublikasikan. The City University of New York, New York.

Rohdiana, D. 2001. Aktivitas daya tangkap radikal polifenol dalam daun teh. Majalah Jurnal Indonesia. 53-58. 
Rusnayanti, Y., Zainuri, dan S. Saloko. 2018. Pengaruh suhu dan lama pengeringan terhadap mutu teh hijau daun kakao (Theobrema cacao L.).

Sakanaka, S., Y. Tachibana, dan Y. Okada. 2013. Preparation and antioxidant properties of extracts of japanese persimo leaf tea (kakinocha-cha). Food chemistry. 89:569575 .

Saragih, R. 2014. Uji kesukaan panelis pada teh daun torbangun (Coleus amboinicus). Jurnal Kesehatan dan Lingkungan. 1(1): 46-52.

Sarastani, D., S.T. Soekarto, T.R. Muchtadi, D. Fardiaz, dan A. Apriyantono. 2002. Aktivitas Antioksidan Ekstrak dan Fraksi Ekstraksi Biji Atung (Parinarium glaberrimum Hassk). Jurnal Teknologi dan Industri Pangan. 13(2).

Sari, M.A. 2015. Aktivitas antioksidan teh daun alpukat (Persea americana Mill.) dengan variasi teknik dan lama pengeringan. Skripsi. Tidak dipublikasikan. Fakultas Keguruan dan Ilmu Pendidikan Universitas Muhammadiyah Surakarta, Surakarta.

Satriadi, I. W. A., N. L. P. Wrasiati, dan I. G. A. L. Triani. 2014. Pengaruh suhu pengeringan dan ukuran potongan terhadap karakteristik teh kulit lidah buaya (Aloe barbadensis Milleer). Jurnal Rekayasa dan Manajemen Agroindustri. 3(2):120-129.

Shah, P., H. A. Modi. 2015. Comparative study of DPPH, ABTS, and FRAP assays for determining antioxidant potential of water and methanol extracts of Spirulina platensis. Indian Journal of Geo-Marine Sciences. 42(5): 556-564.

Simanjuntak, L. 2013. Penerimaan panelis terhadap teh herbal dari kulit buah manggis (Garcinia mangostana L.) dengan perlakuan suhu pengeringan. Jurnal Sagu. 13.2: 7-18

Soekarto, S.T. 1985. Penelitian Organoleptik Untuk Industri Pangan dan Hasil Pertanian. Bharata Karya Aksara, Jakarta.
Steel, R. G. D., dan J. H. Torrie. 1993. Prinsip dan Prosedur Statistika. Penerjemah B. Sumantri. Gramedia Pustaka, Jakarta. 748.

Sudarmadji, S., B. Haryono, dan Suhardi. 1997. Prosedur Analisis untuk Bahan Makanan dan Pertanian. Liberty, Yogyakarta.

Suhardi. 1997. Analisis Senyawa Polifenol Produk Buah-buahan dan Sayuran Vol.3. Yogyakarta. Laboratorium Kimia-Biokimia Pengolahan Fakultas Teknologi Pertanian Universitas Gadjah Mada, Yogyakarta.

Taib, G., G. Said dan S. Wiraatmadja. 1997. Operasi Pengeringan Pada Pengolahan Hasil Pertanian. Mediyatama Sarana Perkasa, Jakarta.

Wazir, D., S. Ahmad., R. Muse., M. Mahmood., M.Y. Shukor. 2011. Antioxidant activities of different parts of Gnetum gnemon L. Journal Plant Biochemistry and Biotechnology. 20(2):234-240.

White, T. 1957. Tannins their occurences and significance. J Sci Food Agric. 8:377-384

Widodo, P., dan A. Hendriadi. 2004. Perbandingan kinerja mesin pengering jagung tipe bak datar model segiempat dan silinder. Jurnal Engineering Pertanian. 2(1).

Winarno, F. G. 1995. Kimia Pangan dan Gizi. Gramedia Pustaka Utama, Jakarta.

Winarno, F. G. 2002. Kimia Pangan dan Gizi. Gramedia Pustaka Utama, Jakarta.

Winarsi, Hery. 2007. Antioksidan Alami dan Radikal Bebas Potensi dan Aplikasi dalam Kesehatan. Kanisius, Yogyakarta.

Winarsi, Hery. 2011. Antioksidan Alami dan Radikal Bebas. Kanisius, Yogyakarta.

Wijana, S., Sucipto dan L. M. Sari. 2014. Pengaruh Suhu dan Waktu Pengeringan terhadap Aktivitas Antioksidan pada Bubuk Kulit Manggis. Skripsi. Tidak dipublikasikan. Fakultas Pertanian Universitas Brawijaya, Malang.

Xu, B. J., S. K. C. Chang. 2007. A comparative on phenolic profiles and antioxidant activities 
of legumes as affected by extraction solvents. Journal of food Science. 72(2):159-166.

Yuldasheva, L.N., E.B. Carvalho, M.T.J.A. Catanho, dan O.U. Krasinikou. 2004. Cholesterol dependent hemolytic activity of passiflora quadrangularis leaves: Brazilian Journal of medical and Biological Research. 38: 1061- 1070.

Xu, B. J., S. K. C. Chang. 2007. A comparative on phenolic profiles and antioxidant activities of legumes as affected by extraction solvents. Journal of food Science. 72(2):159-166.

Zainol, M.K.M., Hamid, A.A., Bakar, F.A., Dek, S.P. 2009. Effect of different drying methods on the degradation of selected flavonoids in Centella asiatica. International Food Research Journal 16: 531-537. 